\title{
Water Use Trends in Washington 1985-2005
}

\section{Introduction}

Since 1950, the U.S. Geological Survey Washington Water Science Center (USGS-WAWSC) has collected, compiled, and published, at 5-year intervals, statewide estimates of the amounts of water withdrawn and used for various purposes in Washington State. As new data and methods became available, some of the original datasets were recompiled. The most recent versions of these datasets were used in this fact sheet. The datasets are available online along with other USGS-WAWSC water-use publications at the USGS-WAWSC water use web page:

http://wa.water.usgs.gov/data/wuse/. Values on these datasets and in this fact sheet may not sum to the indicated total due to independent rounding.

Due to variations in data requirements, collection methods, terminology, and data sources, the direct assessment of water-use trends between compilations is difficult. This fact sheet focuses on the trends in total State and public-supplied populations, freshwater withdrawals and use, public-supply withdrawals and deliveries, and crop irrigation withdrawals and acreage in Washington from 1985 through 2005. These four categories were included in all five compilations and were the most stable in terms of data requirements, collection methods, terminology, and data sources.

\section{Population}

Between 1985 and 2005, the total population in Washington State increased 44 percent from 4.38 to 6.29 million people (fig. 1). During the same period, the population served by class A public-supply systems increased 56 percent from 3.53 to 5.49 million people. The percentage of total population served by class A public-supply systems increased from 81 percent in 1985 to 87 percent in 2005.

\section{Freshwater Withdrawals}

Total freshwater withdrawals in Washington for 1985 were estimated to be 5,180 million gallons per day (Mgal/d) with surface water accounting for 74 percent $(3,850 \mathrm{Mgal} / \mathrm{d})$ and groundwater accounting for 26 percent $(1,330 \mathrm{Mgal} / \mathrm{d})$ of the total (fig. 1). By 2005, freshwater withdrawals had increased 12 percent to $5,780 \mathrm{Mgal} / \mathrm{d}$, with surface water still accounting for 74 percent $(4,280 \mathrm{Mgal} / \mathrm{d})$ and groundwater accounting for 26 percent $(1,490 \mathrm{Mgal} / \mathrm{d})$ of the total. Additionally, between 1985 and 2005:

- Surface-water withdrawals accounted for 71 percent of the estimated total freshwater withdrawals from 1985 to 2005.

- Groundwater withdrawals accounted for 29 percent of the estimated total freshwater withdrawals from 1985 to 2005.
Figure 1. Populations and freshwater withdrawals. 


\section{Freshwater Use}

Between 1985 and 2005, Public Supply accounted for 20 percent of freshwater withdrawals (fig. 2), 15 percent of surface-water withdrawals, and 32 percent of groundwater withdrawals in Washington. Crop Irrigation accounted for 58 percent of freshwater withdrawals, 62 percent of surfacewater withdrawals, and 49 percent of groundwater withdrawals. Together, these two categories accounted for 78 percent of freshwater withdrawals, 77 percent of surface-water withdrawals, and 81 percent of groundwater withdrawals.

\section{Public-Supply Withdrawals}

Public-supply withdrawals in Washington for 1985 were estimated to be $1,050 \mathrm{Mgal} / \mathrm{d}$, with surface water accounting for 60 percent $(630 \mathrm{Mgal} / \mathrm{d})$ and groundwater accounting for 40 percent (421 Mgal/d) of the total (fig. 3). By 1995, public-supply withdrawals had increased 12 percent to $1,180 \mathrm{Mgal} / \mathrm{d}$, with surface water accounting for 46 percent (548 Mgal/d) and groundwater for 54 percent $(631 \mathrm{Mgal} / \mathrm{d})$ of the total.

- The overall increases in pubic-supply withdrawals from 1985 to 1995 reflect similar increases in public supplied populations and total industrial hours.

- The decrease in surface-water withdrawals and the increase in groundwater withdrawals from 1985 to 1995 may be because much of the population increase was in areas served by new public-supply systems that used groundwater rather than surface water.

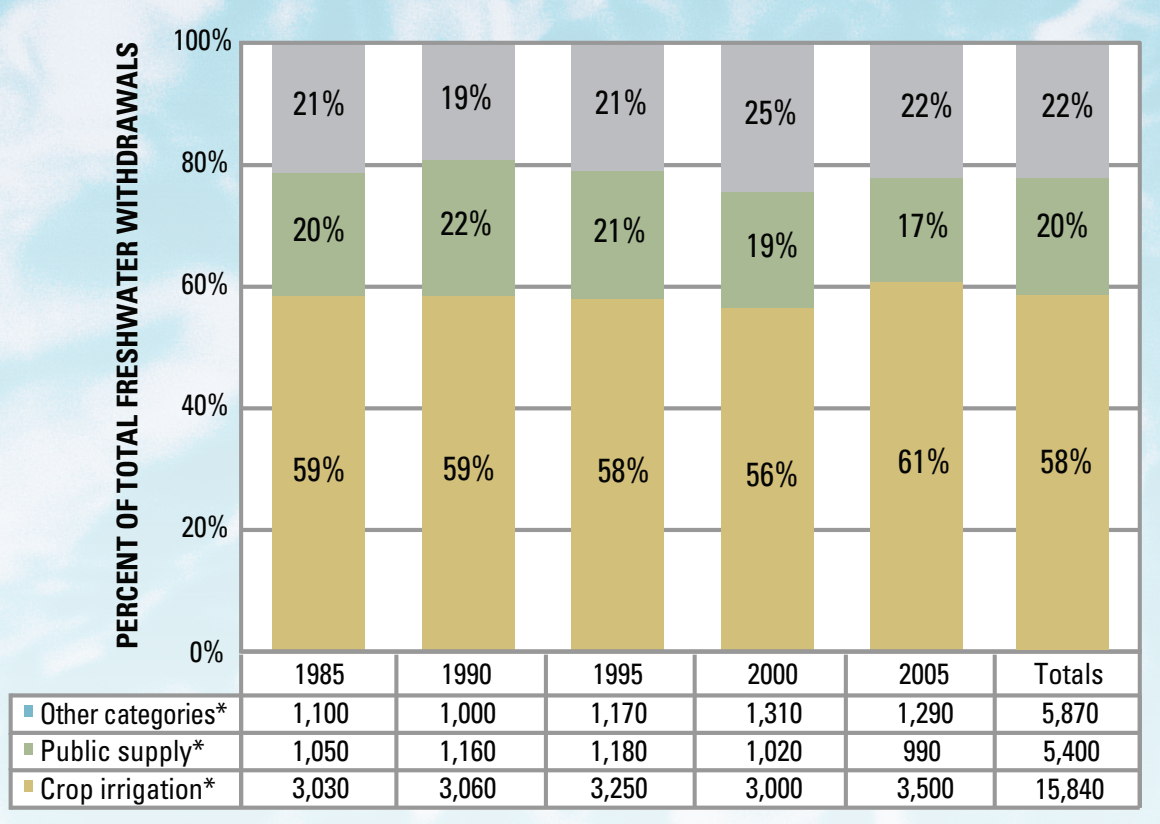

* In million gallons per day

Figure 2. Freshwater by use.

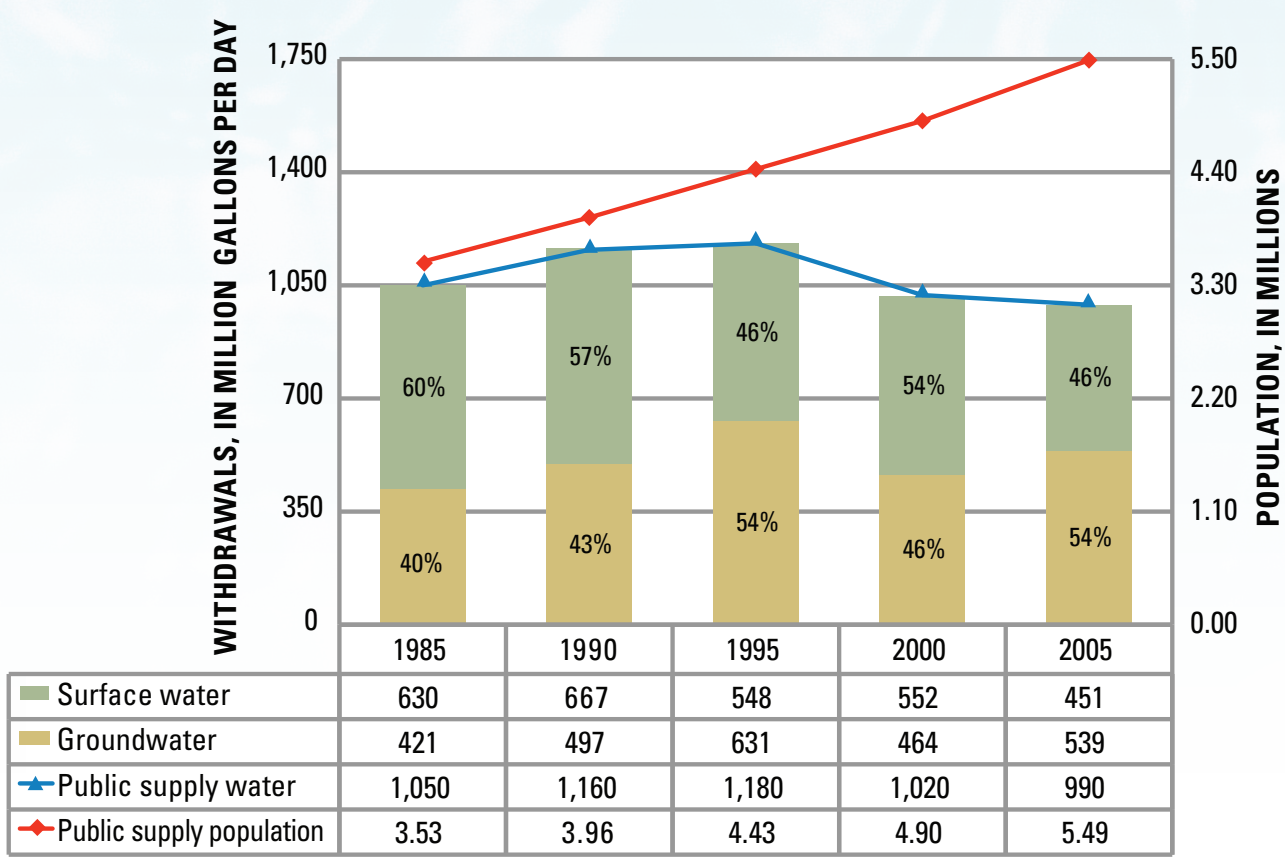

Figure 3. Public-supply withdrawals. 
Between 1995 and 2005, public-supply withdrawals decreased 16 percent from 1,180 to $990 \mathrm{Mgal} / \mathrm{d}$ (fig. 3). Surface-water withdrawals decreased 18 percent from $548 \mathrm{Mgal} / \mathrm{d}$ (54 percent of the total withdrawals) to $451 \mathrm{Mgal} / \mathrm{d}$ (46 percent of the total withdrawals). Groundwater withdrawals decreased 15 percent from $631 \mathrm{Mgal} / \mathrm{d}$ (54 percent of the total withdrawals) to $539 \mathrm{Mgal} / \mathrm{d}$ (also 54 percent of the total withdrawals).

- Although the decreases in public-supply withdrawals from 1995 through 2005 reflect similar changes in public-supply deliveries, the changes also may be linked to changes in the methods used in the 2000 and 2005 compilations.

- The estimated withdrawals for 2000 also may reflect restrictions associated with drought conditions. These restrictions were established and enforced locally by individual systems and included placing limits on the days and times that homeowners were allowed to water yards and gardens.

\section{Public-Supply Deliveries}

Public-supply deliveries for domestic purposes in Washington for 1985 were estimated to be $516 \mathrm{Mgal} / \mathrm{d}$ or 49 percent of the total deliveries (fig. 4). By 1990, domestic deliveries had increased 17 percent to $604 \mathrm{Mgal} / \mathrm{d}$ or 52 percent of the total deliveries. Between 1990 and 2005, domestic deliveries decreased 7 percent from $604 \mathrm{Mgal} / \mathrm{d}$ (52 percent of total deliveries) to $562 \mathrm{Mgal} / \mathrm{d}$ (57 percent of total deliveries). Between 1985 and 1990, the per capita rate for public supplied domestic use increased 5 percent from 146 to 153 gallons per day (gal/d) and then decreased 33 percent to $102 \mathrm{gal} / \mathrm{d}$ in 2005 .

- The increase in domestic deliveries from 1985 to 1990 reflects a 12-percent increase in the public-supply population from 3.53 to 3.96 million people.

- Although the decreases in domestic deliveries between 1990 and 2005 may be linked to the increased emphasis on water-conservation efforts and the increased use of water efficient appliances and other low-flow devices, the decreases also may be linked to changes in the methods used in the 2000 and 2005 compilations.

- The decrease in domestic deliveries for 2000 also may reflect restrictions associated with drought conditions. These restrictions were established and enforced locally by individual systems and included placing limits on the days and times that homeowners were allowed to water yards and gardens.

Public-supply deliveries for non-domestic use in 1985 were estimated to be $535 \mathrm{Mgal} / \mathrm{d}$ or 51 percent of the total deliveries (fig. 4). By 1995, non-domestic deliveries had increased 15 percent to $614 \mathrm{Mgal} / \mathrm{d}$ or 52 percent of the total deliveries. Between 1995 and 2000, non-domestic deliveries decreased 24 percent to $467 \mathrm{Mgal} / \mathrm{d}$ or 46 percent of the total deliveries, and then decreased another 8 percent to $428 \mathrm{Mgal} / \mathrm{d}$ in 2005 .

- The increases in non-domestic deliveries from 1985 to 1995 reflect an increase in industrial production hours from 3.42 million hours in 1985 to a peak of 4.16 million hours in 1995.

- The decreases in non-domestic deliveries from 1995 through 2005 reflect a decrease in industrial production hours from 4.16 million hours in 1995 to 3.71 million hours in 2000, and to 3.01 million hours in 2005 .

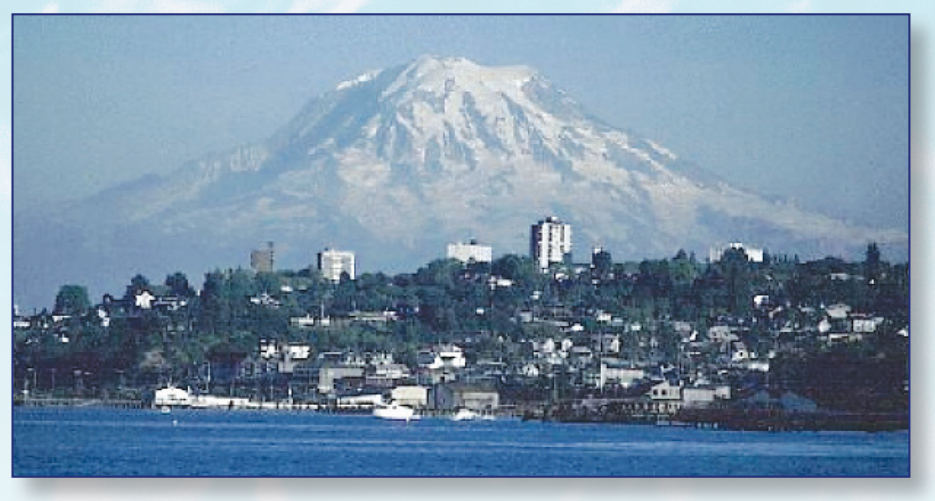

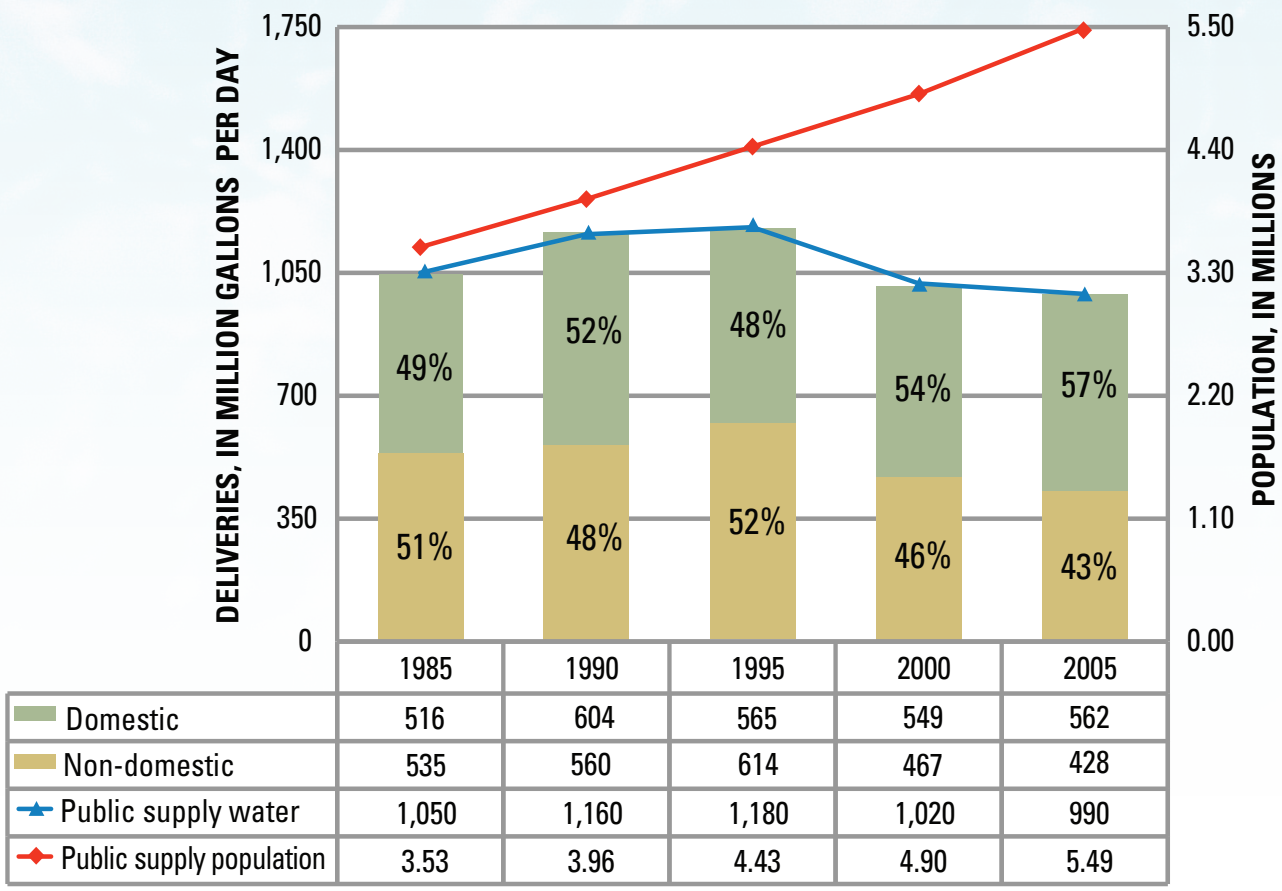

Figure 4. Public-supply deliveries. 
Crop-Irrigation Withdrawals

Crop-irrigation withdrawals in Washington increased 16 percent from 3,030 Mgal/d in 1985 to $3,500 \mathrm{Mgal} / \mathrm{d}$ in 2005 (figs. 5 and 6). Surface-water withdrawals for crop irrigation increased 22 percent from 2,370 Mgal/d in 1985 to $2,890 \mathrm{Mgal} / \mathrm{d}$ in 2005 . Groundwater withdrawals for crop irrigation increased 46 percent from $657 \mathrm{Mgal} / \mathrm{d}$ in 1985 to $960 \mathrm{Mgal} / \mathrm{d}$ in 1995 , and then decreased 36 percent to $613 \mathrm{Mgal} / \mathrm{d}$ in 2005 .

- Between 1985 and 2005, the total application rate for Washington averaged 2.16 feet per year (ft/yr) and ranged from 2.15 to $2.17 \mathrm{ft} / \mathrm{yr}$.

- The decrease in surface water withdrawals for crop irrigation for 2000 may reflect restrictions associated with drought conditions.

- The decrease in groundwater withdrawals for crop irrigation between 1995 and 2005 may be linked to declining groundwater levels in certain areas of the State.

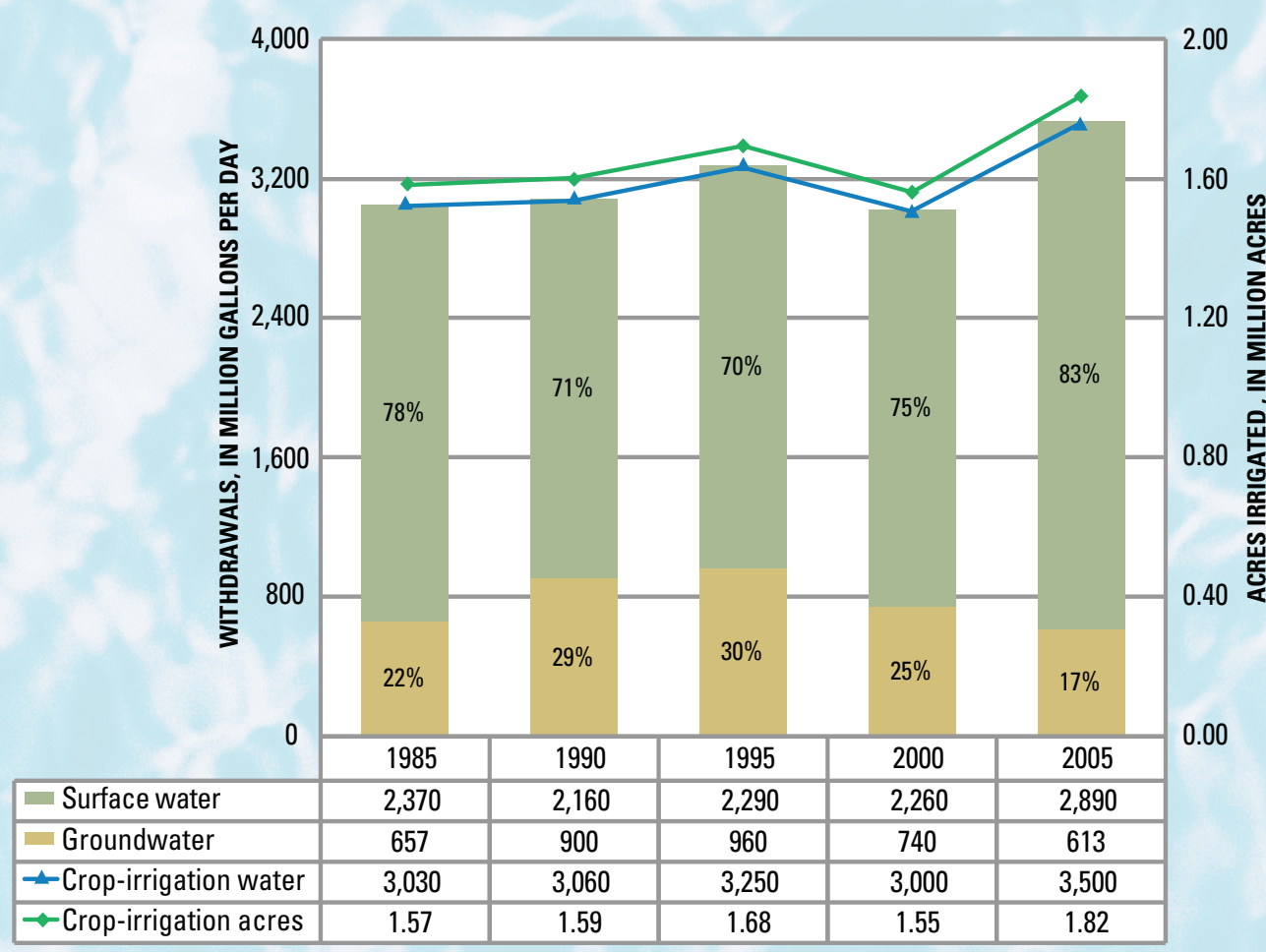

Figure 5. Crop-irrigation withdrawals.

\section{Crop Irrigation and Application Methods}

Crop-irrigation acreage in

Washington increased 16 percent from 1.57 million acres in 1985 to 1.82 million acres in 2005 (figs. 5 and 6). The acreage irrigated by sprinkler methods increased 18 percent from 1.23 million acres in 1985 to 1.45 million acres in 2005 . The acreage irrigated by surface methods decreased 21 percent from 0.34 million acres in 1985 to 0.27 million acres in 2005 . The acreage irrigated by trickle, drip, or other microirrigation methods increased more than 330 percent from 0.03 million acres in 1990 to 0.10 million acres in 2005 .

- Ninety-seven percent of the total crop irrigation acreage is in Eastern Washington.

- The decrease in irrigated acreage for 2000 may reflect restrictions associated with drought conditions.

- The five major crops in Washington, in terms of acres irrigated, are alfalfa, orchards and vineyards, wheat, potatoes, and hay.

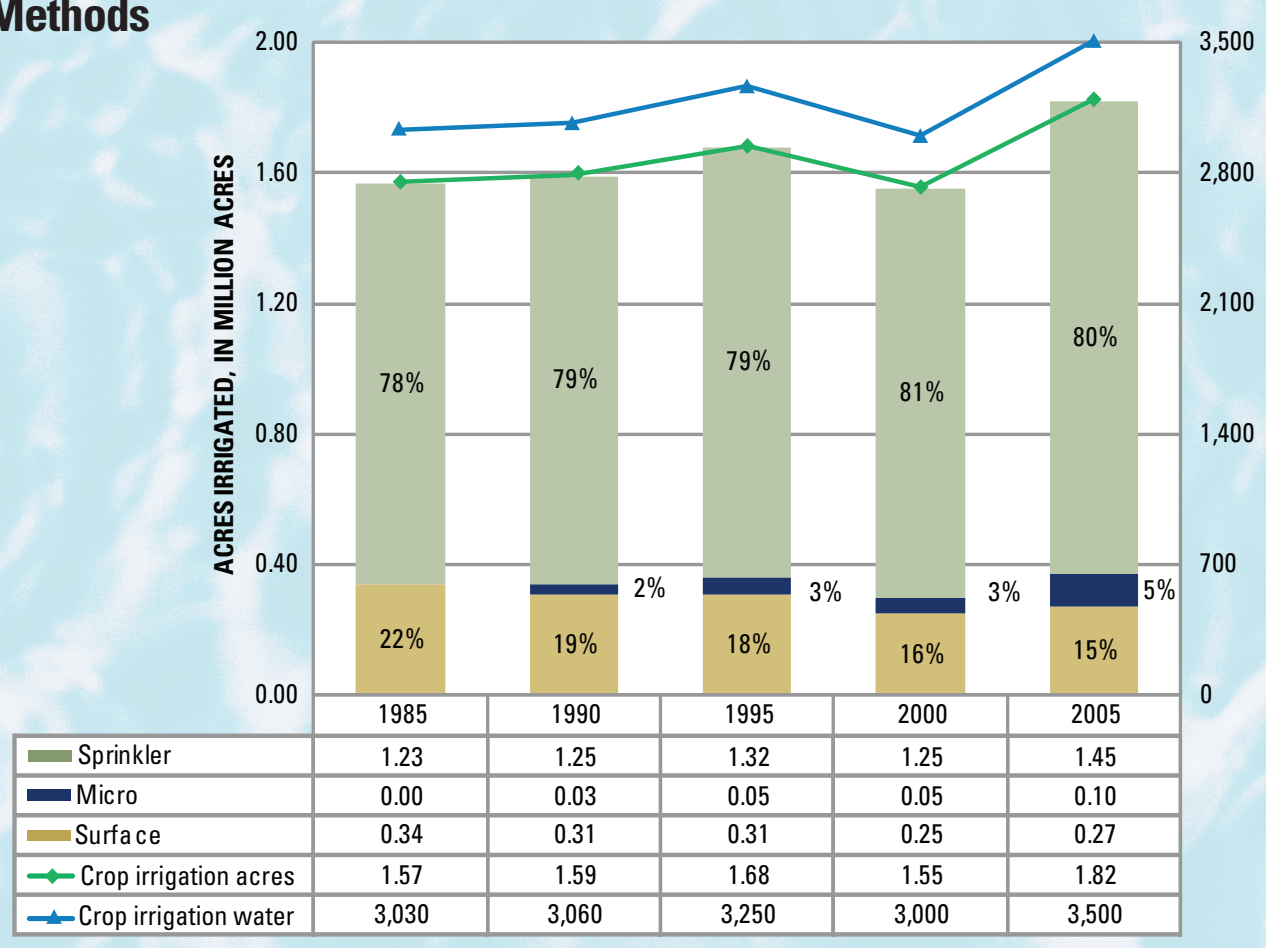

Figure 6. Crop-irrigation acreage and application methods.

\section{Public Inquiries and Data Requests}

Inquiries and requests for data and reports may be made online at the WAWSC web page,

http://wa.water.usgs.gov/pubinfo/

Or by contacting the Public Information Officer, 253-552-1635
Washington Water Science Center at:

U.S. Geological Survey

934 Broadway, Suite 300

Tacoma, Washington 98402

http://wa.water.usgs.gov/ 